\title{
PERSEPSI KONSUMEN TERHADAP PEMBELIAN PRODUK HERBAL DI KABUPATEN SUKOHARJO
}

\author{
Rosita Dewati ${ }^{1)}$ dan Wahyu Adhi Saputro²) \\ 1)Fakultas Pertanian, Jurusan Agribisnis, Universitas Veteran Bangun Nusantara, JI. Letjend S. \\ Humardani No 1 Jombor Sukoharjo, Telp (0271) 593156, email:rosita.dewati@gmail.com \\ 2)Fakultas Sains dan Teknologi, Prodi Agribisnis, Universitas Duta Bangsa Surakarta, Jl. Pinang Raya \\ email: wahyuadhi@udb.ac.id
}

\begin{abstract}
Abstrak
Produk herbal sebenarnya telah lama dikenal dan digunakan oleh masyarakat luas. Mulai dari jamu tradisional, jamu dalam kemasan, madu, sumplemen, vitamin, hingga berbagai jenis obat-obatan untuk mengobati berbagai macam penyakit. Timbulnya berbagai macam penyakit hingga pandemi Covid-19 ini membuat masyarakat lebih peduli terhadap kesehatan diri sendiri maupun keluarga dan lingkungan sekitarnya. Anjuran Kementerian Kesehatan mengenai memanfaatkan produk herbal di masa pandemi untuk menjaga stamina tubuh semakin mendorong keinginan masyarakat untuk mengkonsumsi produk herbal. Penelitian ini bertujuan untuk mengetahui faktor-faktor atau alasan konsumen membeli produk herbal di Kabupaten Sukoharjo. Penelitian ini merupakan penelitian deskriptif dengan menggunakan data primer. Pengambilan sampel dilaksanakan dengan metode purposive sampling sebanyak 104 responden. Instrumen penelitian diuji menggunakan Uji reliabilitas dan validitas. Hasil penelitian di analisis secara deskriptif dan dilakukan uji kecenderungan. Hasil analisis menunjukkan bahwa instrument penelitian valid dan reliable untuk digunakan dalam penelitian. Berdasarkan hasil analisis deskriptif, mayoritas responden berada pada kategori baik. Artinya, 9 variabel dalam penelitian mampu menentukan persepsi konsumen dalam pengambilan keputusan pembelian produk herbal di Kabupaten Sukoharjo. Pengambilan keputusan pembelian produk herbal dipengaruhi oleh label halal, harga produk, rasa, khasiat, kemudahan memperoleh, kedekatan dengan penjual, informasi dalam brosur, informasi dari teman, dan konsep back to nature.
\end{abstract}

Kata kunci: Herbal, Pengambilan Keputusan, Persepsi

\begin{abstract}
Herbal products have been known and used by the community for a long time. Starting from traditional herbs, packaged herbal medicine, honey, supplements, vitamins, and various types of medicines to treat various diseases. The emergence of various kinds of diseases up to the Covid-19 pandemic has made people more concerned about the health of themselves, their families and environment. The Ministry of Health's recommendation regarding the use of herbal products during the pandemic to maintain stamina has encouraged the public's desire to consume herbal products. This study aims to determine the factors or reasons consumers buy herbal products in Sukoharjo Regency. This research is a descriptive study using primary data. Sampling was carried out by purposive sampling method with 104 respondents. The research instrument was tested using validity and reliability tests. The research results were analyzed descriptively and carried out a trend test. The results of the analysis show that the research instrument is valid and reliable for use in research. Based on the results of descriptive analysis, the majority of respondents are in the good category. This means that 9 variables in the study were able to determine consumer perceptions in making decisions about purchasing herbal products in Sukoharjo Regency. The decision to buy herbal products is influenced by the halal label, product price, taste, properties, ease of access, closeness to sellers, information in brochures, information from friends, and back to nature concept.
\end{abstract}

Keywords: Herbs, Perception, Purchasing Decision 


\section{PENDAHULUAN}

Tubuh yang sehat merupakan impian seluruh individu dimanapun. Tidak heran jika masyarakat berlomba-lomba menjaga kesehatan melalui aktivitas olahraga, istirahat yang cukup hingga mengkonsumsi berbagai jenis suplemen dan multivitamin untuk menjaga daya tahan tubuh. Produk-produk suplemen, multivitamin hingga obat-obatan banyak dijumpai di pasaran, mulai dari merk ternama hingga merk lokal buatan masyarakat yang tentunya sudah menagntongi ijin dari BPOM serta ijin edar terkait. Tidak sedikit dari produk-produk tersebut yang mengklaim bahwa produk tersebut adalah produk herbal yang terbuat dari bahan-bahan alami.

Produk herbal sebenarnya telah lama dikenal dan digunakan oleh masyarakat luas. Mulai dari jamu tradisional, jamu dalam kemasan, madu, sumplemen, vitamin, hingga berbagai jenis obat-obatan untuk mengobati berbagai macam penyakit. Di Indonesia sendiri, produk herbal identik dengan sebutan obat tradisional atau obat herbal. Obat herbal merupakan bahan atau ramuan yang berasal dari bahan tumbuhan, hewan, mineral, sediaan sarian (galenik) atau campuran dari bahan-bahan tersebut yang telah digunakan secara turun temurun untuk mengobati berbagai macam penyakit berdasarkan norma yang berlaku di masyarakat (Kementerian Kesehatan, 2012).

Timbulnya berbagai macam penyakit hingga pandemi Covid-19 ini membuat masyarakat lebih peduli terhadap kesehatan diri sendiri maupun keluarga dan lingkungan sekitarnya. Seperti yang dilansir dari portal berita Kemenkes pada tanggal 21 Mei 2020, Kementerian Kesehatan menyarankan masyarakat untuk memanfaatkan obat tradisional berupa jamu, obat herbal terstandar, dan fitofarmaka untuk memelihara memelihara kesehatan, pencegahan penyakit, dan perawatan kesehatan termasuk pada masa kedaruratan kesehatan masyarakat atau bencana nasional Covid-19. Akan tetapi, pemanfaatan obat tradisional tersebut harus tetap memperhatikan beberapa aspek seperti petunjuk penggunaan, surat izin edar dari BPOM, serta informasi-informasi dalam kemasan produk serta obat tradisional tidak boleh digunakan dalam keadaat gawat darurat serta keadaan yang berpotensi membahayakan jiwa (Kementerian Kesehatan, 2020). Hal tersebut semakin mendorong keinginan masyarakat untuk mengkonsumsi produk herbal. Penelitian ini bertujuan untuk mengetahui faktor-faktor atau alasan konsumen membeli produk herbal di Kabupaten Sukoharjo.

\section{BAHAN DAN METODE}

Penelitian ini merupakan penelitian deskriptif dengan menggunakan data primer. Pengambilan sampel dilaksanakan dengan metode purposive sampling atau secara sengaja dimana responden haruslah seseorang yang berdomisili di Kabupaten Sukoharjo dan pernah menggunakan produk herbal. Dari 150 kuisioner yang terisi, hanya 104 kuisioner yang memenuhi syarat pengambilan sampel, dimana sampel harus merupakan masyarakat yang tinggal di Kabupaten Sukoharjo. Teknik pengumpulan data dilakukan dengan menyebarkan angket/kuesioner kepada responden.

Untuk mengetahui validitas kuisioner, dilakukan uji validitas dengan melihat nilai $r$ hitung dan $r$ tabel. Suatu kuisioner dikatakan valid apabila pertanyaan dalam kuisioner mampu mengungkapkan sesuatu yang akan diukut oleh kuisioner (Gozhali, 2016). Uji Validitas dilakukan dengan rumus :

$$
r=\frac{n(\Sigma x)-(\Sigma x)(\Sigma y)}{\sqrt{\left[n\left(\Sigma x^{2}\right)-\left(\Sigma x^{2}\right)\right]}\left[n\left(\Sigma y^{2}\right)-\left(\Sigma y^{2}\right)\right.}
$$

Keterangan :

x $\quad$ : skor variable (jawaban responden)

y : skor total cariabel untuk responden

n : jumlah responden 
Kriteria pengamilan keputusan item pertanyaan valid jika $r$ hitung $>r$ tabel.

Reliabilitas adalah alat untuk mengukur suatu kuisioner yang merupakan indicator dari variable atau konstruk. Suatu kuisioner dikatakan reliabel jika jawaban seseorang terhadap pernyataan konsisten atau stabil dari waktu ke waktu (Gozhali, 2016). Uji Reliabilitas pada penelitian ini dilakukan dengan rumus Cronbach Alpha :

$r_{1}=\left[\frac{k}{k-1}\right]\left[1-\frac{\Sigma \sigma_{b}^{2}}{\sigma_{t}^{2}}\right]$

Keterangan :

$\Sigma \sigma_{b}{ }^{2}$ : jumlah varian butir

$\sigma_{t}^{2} \quad$ : varians total

k : jumlah butir pertanyaan

r_1 : koefisien reliabilitas instrument

Kategorisasi dan Uji Kecenderungan

Analisis deskriptif dilakukan dengan menghitung nilai mean, standar deviasi, varian, skor maksimum dan minimum. Hasil tersebut digunakan untuk melakukan pengkategorian skor dari masing-masing variable. Kemudian dilakukan uji kecenderungan untuk mengetahui gambaran umum masing-masing variabel bebas dan terikat dalam penelitian, dengan menggunakan rumus pada Tabel 1 (Sudijono, 2012).

\section{HASIL DAN PEMBAHASAN}

Uji validitas dan reliabilitas dilakukan pada 35 kuisioner yang sudah diisi oleh responden, diluar responden penelitian. Hasil uji validitas pada kuisioner penelitian ini tersaji pada Tabel 2, dimana dari 9 poin pertanyaan menunjukkan bahwa seluruh pertanyaan valid dengan nilai $r$ hitung $>r$ tabel. Hasil uji reliabilitas menunjukkan nilai Cronbach Alpha (Tabel 3) sebesar 0,716 lebih dari 0,6, sehingga variabel penelitian memenuhi persyaratan untuk digunakan dalam penelitian

\section{Karakteristik Responden}

Responden dalam penelitian ini berjumlah 104 yang sebagian besar merupakan golongan usia produktif antara 15-64 tahun (sebanyak 103 responden). Sedangkan satu responden sisanya termasuk golongan usia tidak produktif. Menurut jenis kelamin, 72,1 \% responden berjenis kelamin wanita dan sisanya $27,9 \%$ laki-laki (Tabel 4).

Pada penelitian ini, hanya Sebagian kecil responden yang menempuh Pendidikan kurang dari 12 tahun (SD dan SMP). Sebesar $18 \%$ responden menempuh Pendidikan hingga SMA, 3\% responden menempuh Pendidikan diploma. Mayoritas responden, sebanyak $64 \%$ menempuh Pendidikan hingga sarjana. Tingkat Pendidikan tertinggi responden dalam penelitian ini adalah pasca sarjana (S2) (Tabel 4)..

Berdasarkan hasil penelitian (Tabel 4)., mayoritas responden dalam penelitian bekerja sebagai karyawan swasta (39,4\%). Sisanya, responden bekerja sebagai PNS, wiraswasta, mahasiswa, ibu rumah tangga, dosen dan lainnya (buruh, pegawai BUMD dan freelancer). Dari sisi pendapatan, mayoritas pendapatan responden dalam penelitian ini > 3.000 .000 per bulan $(51 \%)$, sisanya sebanyak $27,9 \%$ berpendapatan $<1.000 .000$ dan 21,2 $\%$ berpendapatan antara 1.000 .000 sampai 3.000.000.

\section{Konsumsi Produk Herbal}

Produk Herbal yang dimaksud dalam penelitian ini adalah produk kesehatan yang berupa ramuan dari bahan tumbuhan, hewan, mineral, atau campuran bahan-bahan tersebut. Beberapa contoh produk herbal yang dimaksudkan dalam penelitian ini, yang banyak dijumpai di masa pandemi adalah produk herbal yang berkhasiat untuk menjaga imunitas tubuh, seperti : jamu-jamuan, madu, wedang uwuh kemasan, jahe/kunyit/temu lawak instan, produk pencegah masuk angin, 
serta produk lain yang dapat ditemui di sekitar lingkungan masyarakat. Hasil analisis pada penelitian ini (Tabel 5) menunjukkan bahwa mayoritas responden mengkonsumsi produk herbal lebih dari 3 kali dalam 1 bulan $(51,9 \%)$. Sebanyak 18,3\% responden jarang mengkonsumsi produk herbal $(<3$ kali dalam 1 bulan), 15,4\% responden mengkonsumsi produk herbal jika sakit dan sebesar $14,4 \%$ responden mengkonsumsi setiap hari. Hal tersebut menunjukkan bahwa responden lebih sadar untuk menjaga kesehatan dengan mengkonsumsi produk herbal, tanpa harus menunggu saat sakit. Jenis produk herbal yang beredar dalam masyarakat dapat berbentu cairan, jus, kapsul, minyak maupun suplemen. Pada penelitian ini, mayoritas responden mengkonsumsi produk herbal dalam bentuk cairan $(29,8 \%)$ baik dalam bentuk sirup, jamu, madu, maupun produk cair lainnya (Gambar 1). Responden juga lebih menyukai mengkonsumsi lebih dari satu produk seperti cairan dengan suplemen dan minyak $(21,2 \%)$. Produk herbal dalam bentuk minyak kurang diminati oleh responden dalam penelitian ini (10,6\%). Sejalan dengan penelitian Ismarani (2013) jenis obat herbal dalam bentuk minyak seperti minyak habbatussauda, minyak zaitun, minyak vicol kurang disukai responden karena kurang nyaman jika dikonsumsi secara langsung. Akan tetapi responden lebih menyukai mengunakan produk berbentuk minyak untuk pemakaian luar.

\section{Persepsi Konsumen}

Hasil kategorisasi skor rata-rata (Tabel 6) menunjukkan bahwa mayoritas responden memiliki persepsi baik (62\%). Sebesar 42\% responden dalam kategori sangat baik dan masing-masing $1 \%$ untuk kategori kurang baik dan tidak baik. Mayoritas responden berada pada kategori baik artinya 9 variabel seperti label halal, harga produk, rasa, khasiat, kemudahan memperoleh, kedekatan dengan penjual, informasi dalam brosur, informasi dari teman, dan konsep back to nature mampu menentukan persepsi konsumen dalam pengambilan keputusan pembelian produk herbal di Kabupaten Sukoharjo.

\section{Faktor yang Mempengaruhi Pembelian Produk Herbal}

Hasil penelitian menunjukkan (Tabel 7) bahwa mayoritas responden memperhatikan label halal pada saat membeli dan mengkonsumi produk herbal. Sebanyak $74 \%$ responden berpendapat sangat setuju dan $24 \%$ berpendapat setuju. Label halal merupakan hal yang penting khususnya bagi konsumen muslim sehingga konsumen akan memperhatikan keberadaan label ini saat akan membeli sesuatu, termasuk produk herbal. Penelitian Dewi et al. (2019)) menunjukkan bahwa persepsi masyarakat mengenai obat tradisional adalah mengandung bahan yang lebih aman (halal). Menurut Setyawan et al. (2011) perhatian, pemahaman dan ingatan konsumen mengenai label halal yang terdapat pada kemasan produk sangat berkaitan dengan keputusan pembelian.

Pada variabel harga produk, sebesar 29\% responden menyatakan sangat setuju dan 61 $\%$ responden setuju. Hal ini mengisyaratkan bahwa harga produk mempengaruhi keputusan pembelian (persepsi) konsumen dalam membeli produk herbal. Konsumen akan mempertimbangkan harga produk pada saat akan membeli produk herbal. Sedangkan $10 \%$ tidak setuju dan $1 \%$ sangat tidak setuju terhadap harga produk. Konsumen yang berpendapat tidak setuju menunjukkan bahwa harga tidak menjadi tolak ukur atau hal yang mempengaruhi konsumen saat membeli produk herbal. Artinya, pada harga berapapun, konsumen bersedia untuk membeli.

Sebanyak $20 \%$ dan $53 \%$ responden berpendapat sangat setuju dan setuju terhadap variabel rasa. Artinya, rasa produk 
akan berpengaruh terhadap keputusan pembelian produk herbal. Sedangkan 25\% dan $2 \%$ sisanya berpendapat tidak setuju dan sangat tidak setuju, yang menunjukkan bahwa responden tidak mempertimbangkan rasa produk herbal saat akan membeli. Hal ini dapat disebabkan karena konsumen lebih mempertimbangkan khasiat produk daripada harga dan rasa. Pendapat tersebut didukung oleh hasil penelitian ini pada variabel khasiat dimana $65 \%$ dan $34 \%$ responden sangat setuju dan setuju. Didukung oleh penelitian Marwati \& Amidi (2019) yang menyatakan bahwa pada persepsi konsumen obat herbal terbentuk makna bahwa obat herbal itu terjamin, cepat sembuhnya, berkhasiat dan terbukti menyembuhkan. Menurut hasil penelitiannya, konsumen yang menggunakan obat herbal pada umumnya merasakan beberapa khasiat yang diyakininya.

Responden berpendapat bahwa mudah untuk memperoleh produk herbal, dimana mayoritas responden setuju $(60 \%)$ dan sangat setuju (38\%) bahwa produk herbal mudah diperoleh yang artinya di sekitar responden tersedia berbagai macam jenis produk herbal sehingga tidak sulit untuk menemukan produk herbal.

Kedekatan dengan penjual menggambarkan bahwa responden dapat dengan mudah menemukan penjual/gerai/toko yang menjual produk herbal di sekitar lingkungan tempat tinggal mereka. Sebanyak $24 \%$ responden menjawab sangat setuju dan $61 \%$ menjawab setuju. Hasil tersebut menunjukkan bahwa responden dekat dengan penjual, dan faktor tersebut menjadi pertimbangan konsumen dalam membeli produk herbal. Sementara itu, sebanyak $13 \%$ dan $2 \%$ responden menyatakan tidak setuju dan sangat tidak setuju terhadap kedekatan dengan penjual menjadi faktor yang dipertimbangkan. Artinya, responden tidak bermasalah dengan penjual yang jauh dari lingkungan responden. Kemungkinan lain, dimana responden dapat melakukan pembelian online di era industri
4.0 ini, sehingga kedekatan atau jarak dengan penjual tidak menjadi masalah bagi konsumen.

Informasi merupakan hal yang penting dalam mempengaruhi keputusan pembelian suatu produk karena semakin banyak informasi yang diperoleh akan semakin banyak pula pengetahuan seseorang terhadap produk tersebut sehingga dapat menyebabkan timbulnya berbagai pertimbangan dalam pengambilan keputusan mengkonsumsi produk tersebut. Responden dalam penelitian ini menyatakan bahwa $13 \%$ dan $67 \%$ sangat setuju dan setuju bahwa informasi dalam brosur mempengaruhi keputusan pembelian produk herbal. Penelitian Ismail (2015) menyatakan bahwa informasi berpengaruh terhadap keputusan pembelian obat tradisional. semakin banyak informasi yang diperoleh masyarakat tentang pemilihan obat tradisional, kemungkinan masyarakat memilih obat tradisional semakin tinggi. Informasi dapat menambah wawasan masyarakat mengenai obat tradisional. Sedangkan 20\% responden tidak setuju bahwa informasi mempengaruhi keputusan pembelian produk herbal. Hal ini dapat disebabkan karena responden sudah mengetahui informasi mengenai produk herbal dari sumber lain sehingga tidak membaca brosur produk. Selain itu, informasi dari teman turut menjadi faktor yang dipertimbangkan oleh responden dalam membeli produk herbal. Sebanyak 16\% dan $69 \%$ responden menyatakan sangat setuju dan setuju. Melalui keluarga teman dan tetangga, konsumen dapat memperoleh informasi dan masukan sebagai pertimbangan pengambilan keputusan dalam menggunakan obat herbal (Maryani et al., 2017). Sama halnya dengan informasi dari brosur, terdapat $13 \%$ dan $1 \%$ responden menyatakan tidak setuju dan sangat tidak setuju bahwa informasi dari teman menjadi faktor yang mempengaruhi pembelian. Hal ini dapat pula disebabkan responden mendapatkan informasi produk herbal dari sumber lain. 
Di era pandemic ini seperti yang dianjurkan oleh Kementrian Kesehatan bahwa mengkonsumsi produk herbal baik untuk menjaga kesehatan dan daya tahan tubuh. $\mathrm{Hal}$ ini membuat produk-produk herbal semakin diminati masyarakat. Hal tersebut berkaitan dengan konsep kembali ke alam (back to nature). Berdasarkan hasil penelitian, konsep Kembali ke alam mempengaruhi keputusan pembelian produk herbal. Sebanyak $45 \%$ dan $49 \%$ responden menyatakan sangat setuju dan setuju. Hanya $5 \%$ dan $1 \%$ responden yang menyatakan tidak setuju dan sangat tidak setuju bahwa konsep back to nature mempengaruhi keputusan pembelian produk herbal. Hal tersebut dapat berarti bahwa memang konsumen sudah sejak lama mengetahui khasiat dan keuntungan mengkonsumsi produk herbal sejak dahulu, sehingga booming atau tidaknya konsep back to nature ini tidak berpengaruh terhadap keputusan pembelian produk herbal.

\section{SIMPULAN}

Hasil penelitian menunjukkan bahwa 9 variabel yang diteliti yakni label halal, harga produk, rasa, khasiat, kemudahan memperoleh, kedekatan dengan penjual, informasi dalam brosur, informasi dari teman, dan konsep back to nature, .mempengaruhi persepsi masyarakat dalam pengambilan keputusan pembelian produk herbal di Kabupaten Sukoharjo.

\section{DAFTAR PUSTAKA}

Dewi, R. S., Aryani, F., Pratiwi, E., \& Agustini, T. T. (2019). Persepsi Masyarakat Mengenai Obat Tradisional di Kecamatan Tampan Kota Pekanbaru. Penelitian Farmasi Indonesia, 8(2), 75-79.

Gozhali, I. (2016). Aplikasi Analisis Multivariate dengan Program IBM SPSS 23. Badan Penerbit Universitas
Diponegoro.

Ismail, I. (2015). Faktor Yang Mempengaruhi Keputusan Masyarakat Memilih Obat Tradisional Di Gampong Lam Ujong. Idea Nursing Journal, 6(1), 7-14.

Ismarani. (2013). Kajian Persepsi Konsumen Terhadap Penggunaan Obat Herbal ( Kasus Di Unisma Bekasi). CEFARS; Jurnal Agribisnis Dan Pengembangan Wilayah, 4(2), 52-63.

Kementerian Kesehatan. (2012). Peraturan Menteri Kesehatan Republik Indonesia Nomor 006 Tahun 2012 (Vol. 66, Issue 2).

Kementerian Kesehatan. (2020). Kemenkes Sarankan Masyarakat Manfaatkan Obat Tradisional.

http://sehatnegeriku.kemkes.go.id/baca/ri lis-media/20200521/4433937/kemenkessarankan-masyarakat-manfaatkan-obattradisional/

Marwati, M., \& Amidi, A. (2019). Pengaruh Budaya, Persepsi, Dan Kepercayaan Terhadap Keputusan Pembelian Obat Herbal. Jurnal IImu Manajemen, 7(2), 168.

https://doi.org/10.32502/jimn.v7i2.1567

Maryani, H., Kristiana, L., \& Lestari, W. (2017). Faktor Dalam Pengambilan Keputusan Pembelian Jamu Saintifik. Buletin Penelitian Sistem Kesehatan, 19(3).

https://doi.org/10.22435/hsr.v19i3.6327.2 $00-210$

Setyawan, A., Sandi, P., \& Rahmawanto, D. (2011). Persepsi Label Halal. Jurnal Manajemen Bisnis, 1(2), 135-143.

Sudijono, A. (2012). Pengantar Statistik Pendidikan. Raja Grafindo Persada. 
Dewati \& Saputro. 2020

Vol. 4, No. 2, 2020

\section{Lampiran}

Tabel 1. Kecenderungan Skor Rata-Rata

\begin{tabular}{ll}
\hline Kecenderungan Skor Rata-rata & Kategori \\
\hline $\mathrm{X} \geq(\mathrm{Mi}+1,5 \mathrm{SDi})$ & Sangat Baik \\
$\mathrm{Mi} \leq \mathrm{X}<(\mathrm{Mi}+1,5 \mathrm{SDi})$ & Baik \\
$(\mathrm{Mi}-1,5 \mathrm{SDi}) \leq \mathrm{X}<\mathrm{Mi}$ & Kurang Baik \\
$\mathrm{X}<(\mathrm{Mi}-1,5 \mathrm{SDi})$ & Sangat Kurang Baik \\
\hline
\end{tabular}

Tabel 2. Hasil Uji Validitas

\begin{tabular}{llccc}
\hline No & Butir Soal & rhitung & rtabel & Keterangan \\
\hline 1 & Label Halal & 0,373 & 0,324 & Valid \\
2 & Harga Produk & 0,710 & 0,324 & Valid \\
3 & Rasa & 0,393 & 0,324 & Valid \\
4 & Khasiat & 0,543 & 0,324 & Valid \\
5 & Kemudahan Memperoleh & 0,600 & 0,324 & Valid \\
6 & Kedekatan Dengan Penjual & 0,523 & 0,324 & Valid \\
7 & Informasi dalam Brosur & 0,344 & 0,324 & Valid \\
8 & Informasi Dari Teman & 0,687 & 0,324 & Valid \\
9 & Konsep Back To Nature & 0,447 & 0,324 & Valid \\
\hline
\end{tabular}

Tabel 3. Hasil Uji Reliabilitas

\begin{tabular}{ll}
\hline Cronbach's Alpha & N of ltems \\
0,716 & 10 \\
\hline
\end{tabular}


Agrisaintifika

Dewati \& Saputro. 2020

Tabel 4. Karakteristik Responden Menurut Umur

\begin{tabular}{|c|c|c|}
\hline Kategori umur & Frekuensi & Prosentase (\%) \\
\hline$<15$ tahun & 0 & 0 \\
\hline 15-64 tahun & 103 & 99 \\
\hline$>64$ tahun & 1 & 1 \\
\hline \multicolumn{3}{|l|}{ Jenis kelamin } \\
\hline Laki-laki & 29 & 27,9 \\
\hline Perempuan & 75 & 72,1 \\
\hline \multicolumn{3}{|l|}{ Pendidikan } \\
\hline Sd & 1 & 1,0 \\
\hline Smp & 0 & 0,0 \\
\hline Sma & 19 & 18,3 \\
\hline Diploma & 3 & 2,9 \\
\hline Sarjana & 67 & 64,4 \\
\hline Pasca sarjana & 14 & 13,5 \\
\hline \multicolumn{3}{|l|}{ Pendapatan } \\
\hline$<1.000 .000$ & 29 & 27,9 \\
\hline $1.000 .000-3.000 .000$ & 22 & 21,2 \\
\hline$>3.000 .000$ & 53 & 51,0 \\
\hline \multicolumn{3}{|l|}{ Pekerjaan } \\
\hline Pns & 10 & 9,6 \\
\hline Wiraswasta & 16 & 15,4 \\
\hline Karyawan swasta & 41 & 39,4 \\
\hline Mahasiswa & 15 & 14,4 \\
\hline Ibu rumah tangga & 10 & 9,6 \\
\hline Dosen & 4 & 3,8 \\
\hline Lainnya & 8 & 7,7 \\
\hline
\end{tabular}

Tabel 5. Frekuensi Konsumsi Produk Herbal

\begin{tabular}{lcr}
\hline Frekuensi Konsumsi & Frekuensi & \multicolumn{2}{c}{ Prosentase } \\
\hline Setiap hari & 15 & 14,4 \\
Kadang-kadang (> 3x dalam 1bulan) & 54 & 51,9 \\
Jarang (<3x dalam 1bulan ) & 19 & 18,3 \\
Jika sakit & 16 & 15,4 \\
\hline
\end{tabular}


Dewati \& Saputro. 2020

Tabel 6. Persepsi Konsumen dalam Keputusan Pembelian Produk Herbal

\begin{tabular}{llr}
\hline Interval & Kategorisasi & Prosentase \\
\hline$X \geq 30$ & Sangat Baik & 42 \\
$24 \leq X<30$ & Baik & 60 \\
$18 \leq X<24$ & Kurang Baik & 1 \\
$X<18$ & Sangat Kurang Baik & 1 \\
\hline
\end{tabular}

Tabel 7. Faktor yang Mempengaruhi Keputusan Pembelian Produk Herbal

\begin{tabular}{llrrrr}
\hline No & Alasan Pembelian & \multicolumn{5}{c}{ Prosentase (\%) } \\
& & SS & S & TS & STS \\
\hline 1 & Label Halal & 74 & 24 & 1 & 1 \\
2 & Harga Produk & 29 & 61 & 10 & 1 \\
3 & Rasa & 20 & 53 & 25 & 2 \\
4 & Khasiat & 65 & 34 & 0 & 1 \\
5 & Kemudahan Memperoleh & 38 & 60 & 2 & 1 \\
6 & Kedekatan Dengan Penjual & 24 & 61 & 13 & 2 \\
7 & Informasi dalam Brosur & 13 & 67 & 20 & 0 \\
8 & Informasi Dari Teman & 16 & 69 & 13 & 1 \\
9 & Konsep Back To Nature & 45 & 49 & 5 & 1 \\
\hline
\end{tabular}

\section{Jenis Produk Herbal}

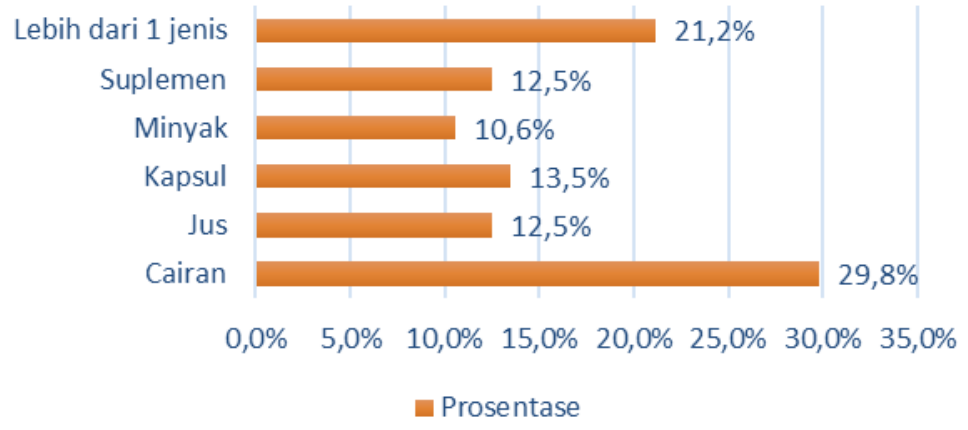

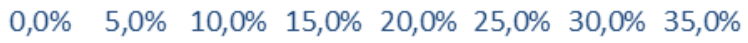

- Prosentase

Gambar 1. Jenis Produk Herbal 